\title{
THE EFFECT OF DIFFERENT PRE-MIXTURES IN NUTRITION OF FATTENERS
}

\author{
B. Živković ${ }^{1}$, W. Migdal ${ }^{2}$, O. Kosovac ${ }^{1}, \check{C}^{.} \operatorname{Radović}^{1}$, S. Pejčić ${ }^{1}$ \\ ${ }^{1}$ Institute for Animal Husbandry, Zemun-Belgrade, Republic of Serbia \\ ${ }^{2}$ Agricultural University, Faculty of Food Technology, Cracow, Poland \\ Corresponding author: zivkovicbbranislav@yahoo.com \\ Original scientific paper
}

Abstract: We have been witnesses to import of numerous premixes produced by various producers and of different quality in regard to concentration of ingredients which are their main components. In our previous studies (Živković et al., 2010) we obtained results confirming that in use of domestic premix more economically efficient production is realized in nutrition of sows and piglets, so this research was carried out with objective to verify the effects of several different imported premixes and those produced according to domestic concept, in nutrition of growing-fattening pigs. Research was performed on private farm in the vicinity of Šabac in Serbia. Nutrition of fattening pigs using mixture which contained adequate premix of domestic production improved the growth rate by $7.6 \%$ without any significant difference in food conversion. Cost of feed when domestic premixes were used in nutrition of fattening pigs was by $4.1 \%$ lower and value of realized pigs by approx. $4.51 \%$ more favourable when domestic premixes were used in nutrition of investigated animals. Dressing percentage of pigs on domestic premixes was higher by $2.0 \%$, and there was no difference in meatiness between compared groups of animals in the experiment. In general, obtained results showed that use of both types of compared premixes can be recommended, but it is more economically efficient to use domestic premixes in nutrition of fattening pigs.

Key words: imported and domestic premixes, fatteners

\section{Introduction}

In modern pig production it is necessary to add certain vitamins, microelements and different additives by way of so called vitamin-mineral premixtures or premixes. The role and importance of vitamins and microelements in nutrition have been pointed in the early nineties (Zlatić, 1983) and late nineties (Cmiljanić et al., 1996; Živković et al., 1996). With the increase of the intensity of pig production and their concentration on one location on the farm, role and importance of premixes in nutrition for the purpose of improvement of production 
and preservation of good health condition became more important from year to year (Živković and Kovčin, 1983).

Absence of premixes from mixtures causes very distinct production depressions, lower gain up to $35 \%$ and lower food conversion by approx. $20 \%$ (Jakobčić et al., 1983). Today, composition of premixes varies depending on the producer and question is how these differences in dosages of vitamins, microelements and additives can influence production results in pig nutrition.

In the last twenty years we have been witnesses to import of numerous premixes from different producers and of different quality in regard to concentration of ingredients which are their main components.

This research, which is the continuation of our investigation, was carried out with objective to verify the effects of several different imported premixes and those produced according to domestic concept, in nutrition of fatteners.

\section{Materials and Methods}

Investigation was carried out on private pig farm of the family Fencaroš in Platičevo in the vicinity of Šabac. Trial included total of 30 fattening pigs divided into two nutrition treatments. Criteria for division of animals were origin, sex and body weight of animals.

In case of all investigated mixtures, levels of crude proteins were equal, fatteners were fed ad libitum as group.

At the end of trial, animals were fed same mixtures and after certain time transported at the same time to slaughterhouse where linear measures on pig carcass sides were taken.

For evaluation of obtained results the following parameters were used: average daily gain feed intake, feed conversion ratio, economical justification for the use of studied premixes through cost of $\mathrm{kg}$ of gain, and slaughter results.

Obtained results were processed statistically using variance analysis, and differences between averages using t-test.

\section{Results and Discussion}

In initial fattening period, pigs of the first group fed diets containing imported pre-mix realized average daily gain of $601 \mathrm{~g}$ (Table 1). Use of domestic pre-mix in mixture lead to improved gain by average of $95 \mathrm{~g}$ or $15.97 \%$ compared to first group of animals.

Pigs fed mixture containing domestic pre-mix consumed $0,23 \mathrm{~kg}$ or $13.53 \%$ more food, and per $1 \mathrm{~kg}$ of gain they used $0.08 \mathrm{~kg}$ or $2.82 \%$ less food than animals fed imported pre-mix. 
Table 1. Performance of fatteners in the experiment

\begin{tabular}{|c|c|c|}
\hline Group & $\begin{array}{c}1 \\
\text { control }\end{array}$ & $\begin{array}{c}2 \\
\text { experimental }\end{array}$ \\
\hline Imported premix in the mixture & + & - \\
\hline Domestic premix in the mixture & - & + \\
\hline \multicolumn{3}{|c|}{ Pigs during growing period, $28-70 \mathrm{~kg}$} \\
\hline Duration of growing period, days & 59 & 59 \\
\hline Average daily gain, $g$ & 601 & 697 \\
\hline Compared to the $1^{\text {st }}$ group, $\%$ & - & +15.97 \\
\hline Average feed intake, $\mathrm{kg}$ & 1.70 & 1.93 \\
\hline Compared to the $1^{\text {st }}$ group, $\%$ & - & +13.53 \\
\hline Feed conversion ratio, kg & 2.84 & 2.76 \\
\hline Compared to the $1^{\text {st }}$ group, $\%$ & - & +2.82 \\
\hline \multicolumn{3}{|c|}{ Pigs during finishing period, $70-101 \mathrm{~kg}$} \\
\hline Duration of finishing period, days & 33 & 33 \\
\hline Average daily gain, $g$ & 984 & 968 \\
\hline Compared to the $1^{\text {st }}$ group, $\%$ & - & -1.63 \\
\hline Average feed intake, $\mathrm{kg}$ & 2.60 & 2.60 \\
\hline Compared to the $1^{\text {st }}$ group, $\%$ & - & 0 \\
\hline Feed conversion ratio, $\mathrm{kg}$ & 2.65 & 2.69 \\
\hline Compared to the $1^{\text {st }}$ group, $\%$ & - & -1.51 \\
\hline \multicolumn{3}{|c|}{ Pigs during whole fattening period, $28-101 \mathrm{~kg}$} \\
\hline Duration of whole fattening period, days & 92 & 92 \\
\hline Average daily gain, $g$ & 738 & 794 \\
\hline Compared to the $1^{\text {st }}$ group, $\%$ & - & +7.59 \\
\hline Average feed intake, $\mathrm{kg}$ & 2.02 & 2.17 \\
\hline Compared to the $1^{\text {st }}$ group, $\%$ & - & +7.42 \\
\hline Feed conversion ratio, kg & 2.74 & 2.73 \\
\hline Compared to the $1^{\text {st }}$ group, $\%$ & - & +0.36 \\
\hline Body weight of pigs at the end of experiment, $\mathrm{kg}$ & 96.67 & 101.73 \\
\hline The age of pigs from farrowing to slaughter weight, days & 167.0 & 167.2 \\
\hline Average live daily gain, $g$ & 569 & 598 \\
\hline
\end{tabular}

In final fattening period with same consumption of food, animals fed imported pre-mix realized by $16 \mathrm{~g}$ or $1.63 \%$ better gain and by $0.04 \mathrm{~kg}$ or $1.51 \%$ more favourable food conversion.

For entire fattening period in duration of 92 feeding days, pigs fed mixture containing domestic pre-mix realized by $56 \mathrm{~g}$ or $7.59 \%$ higher yield, consumed 0.15 
$\mathrm{kg}$ or by $7.42 \%$ more food and consumed for $1 \mathrm{~kg}$ of gain same amount of food, $2.74 \mathrm{~kg}$ and $2.73 \mathrm{~kg}$, compared to fatteners fed diet containing imported pre-mix.

Table 2. Economic analysis of the use of different premixes in the experiment

\begin{tabular}{|l|c|c|}
\hline Group & $\begin{array}{c}1 \\
\text { control }\end{array}$ & $\begin{array}{c}2 \\
\text { experimental }\end{array}$ \\
\hline Imported premix in the mixture & + & - \\
\hline Domestic premix in the mixture & - & + \\
\hline \multicolumn{2}{|c|}{ Fattening pigs } \\
\hline The price of the diets, \% & 100.00 & 95.86 \\
\hline Feed conversion ratio, kg & 2.74 & 2.73 \\
\hline Feed conversion ratio, \% & 100.00 & 99.64 \\
\hline Total price of produced pigs, \% & 100.00 & 95.49 \\
\hline Compared to the $1^{\text {st }}$ group, \% & - & +4.51 \\
\hline
\end{tabular}

Use of domestic premix in mixtures reduces the cost of feed by $4.14 \%$ so with slightly more favourable feed conversion ratio, the cost of gain of pigs in group receiving mixtures with domestic premix was more favourable by $4.51 \%$ compared to control group of animals fed imported premixes, which justifies the use of this type of premixes from nutritive and economical stand point of view in case of this pig category (Table 2).

There were no significant differences in meat yield of fatteners in trial, but animals fed mixture containing domestic pre-mix realized by $2.00 \%$ higher dressing percentage (Table 3)

Table 3. Slaughter measurements of fatteners

\begin{tabular}{|l|c|c|}
\hline Group & $\begin{array}{c}1 \\
\text { control }\end{array}$ & $\begin{array}{c}2 \\
\text { experimental }\end{array}$ \\
\hline Imported premix in the mixture & + & - \\
\hline Domestic premix in the mixture & - & + \\
\hline Body weight of pigs before slaughtering, kg & 111.0 & 122.9 \\
\hline Weight of warm carcasses, kg & 87.8 & 93.8 \\
\hline Fat thickness, mm & & \\
\hline - shoulder & 38 & 37 \\
\hline - midle back & 18 & 19 \\
\hline - loin (average of three measurements) & 21 & 23 \\
\hline Length of carcasses, cm & & \\
\hline - atlas - os pubis & 104.5 & 107.0 \\
\hline - $1^{\text {st }}$ rib - os pubis & 87.8 & 89.0 \\
\hline Dressing percentage, $\%$ & 79.02 & 80.60 \\
\hline Meatiness, $\%$ & 52.77 & 52.47 \\
\hline
\end{tabular}


Differences stated in literature references about needs/requirements of certain micro ingredients in pigs are very different, and among other things depend on genetic potential, housing and environment conditions, health condition, etc. (Kovčin, 1992; Kasalica, 1995; Jokić, 1996, Šefer and Sinovec, 1999). If pigs are of adequate genetic potential, increased concentration of vitamins and micro elements in premixes leads to better gain by 4.4\% (Pupavac et al., 1998) i.e. by $4.6 \%$ (Živković et al., 2005) and more favourable feed conversion ratio by $3.5 \%$ (Pupavac et al., 1998) and even to 5.2\% (Živković et al., 2005). When premixes are formulates, use of non-organic sources of micro elements, it is preferable to apply more free "security" requirements in vitamins (Shurson et al., 1997), although, in regard to freedom in final fattening period of pigs, it is not necessary to include premixes into mixtures (Lee and Kim, 2002).

In production of premixes, the most frequent are variations in concentrations of recommended amounts of vitamins and cost of product which can vary from 2 to 10 dollars per tonne of complete food (Rea and Veum, 1993), so in general, when formulating mixtures for realization of maximum production, nutrition is always searching for new knowledge about nutritive value of vitamins and microelements in premixes (Pomar et al., 2009).

\section{Conclusion}

The effects of the use of vitamin-mineral pre-mixtures (premixes), imported and of domestic origin were investigated in nutrition of fatteners. Research was performed on private farm Fencaroš in Platičevo near Šabac. Obtained results showed that:

Pigs fed mixtures containing domestic pre-mix realized better gain by $7.6 \%$ and better food consumption by $7.4 \%$

No significant difference in food conversion between compared groups of animals in the trial was recorded.

Domestic premix in mixtures reduced the cost of mixtures by $4.1 \%$ and reduced the cost of gain in fatteners by $4.5 \%$ compared to nutrition with diets containing imported premixes.

Pigs fed domestic pre-mix, realized by $2.0 \%$ higher dressing percentage determined on slaughter line compared to animals fed imported pre-mix in the mixture, although the meatiness was the same.

In general, obtained results showed that the utilization of both types of compared premixes can be recommended, but it is more economically efficient to use domestic premixes in nutrition of fattening pigs. 


\title{
Acknowledgment
}

Research was financed by the Ministry of Science and Technology Development, Republic of Serbia, project TR 20087.

We would like to thank the family Fencaroš, Platičevo for allowing us to perform trials on their pig farm.

\section{Efekti različitih premiksa u ishrani svinja u tovu}

\author{
B. Živković, W. Migdal, O. Kosovac, Č. Radović, S. Pejčić
}

\section{Rezime}

Poslednjih deset godina svedoci smo uvoza mnogobrojnih premiksa raznih proizvođača različitog kvaliteta u pogledu koncentracija ingredijenata koji ulaze u njihov sastav. Relativno je malo podataka (Živković et al., 2010) o efektima njihove nutritivne vrednosti kod svinja, zbog čega su ova ispitivanja i izvedena sa ciljem da se provere efekti palete premiksa iz uvoza $\mathrm{i}$ onih proizvedenih po domaćem konceptu čiji je idejni tvorac prvoimenovani autor ovoga rada, u ishrani svinja $u$ tovu. Istraživanja su izvedena na privatnoj farmi svinja u Platičevu u okolini Šapca u Srbiji.

Dobijeni rezultati su pokazali da se ishranom tovljenika smešama sa odgovarajućim koncentracijama domaćeg premiksa prirast poboljšava za 7,6\% uz skoro identičnu konverziju hrane. Cena hrane korišćenjem domaćeg premiksa u ishrani je bila za $4,51 \%$ povoljnija te je cena ostvarenog prirasta bila za $4,51 \%$ povoljnija od onoga ostvarenog ishranom smešom istog sastava uz korišćenje premiksa iz uvoza. Na liniji klanja pokazalo se da nije bilo bitne razlike u mesnatosti u polutkama, ali je grupa na obroku sa domaćim premiksom iskazala za $2,0 \%$ povoljniji randman.

U celini dobijeni rezultati su pokazali da se preporučuje korišćenje obeju vrsta upoređivanih premiksa, ali je ekonomičnije koristiti domaće premikse u ishrani svinja $u$ tovu.

\section{References}

CMILJANIĆ R., PAVLOVSKI Z., VLAHOVIĆ M., TRENKOVSKI S., ŽIVKOVIĆ B. (1996): Premiksi i stres. V savetovanje o primeni premiksa u stočnoj hrani, Velika Plana. Veterinarski Zavod, Zemun, 41-45.

JAKOBČIĆ Z., SAVOLD F., ŽIVKOVIĆ S., KOVČIN S., SEGETLIJA Đ. GAGIĆ Đ., HADŽIREŠIĆ M. (1983): Efekat različitih doza vitamina i mikroelemenata u obrocima svinja u porastu i tovu. Krmiva 5, 73-77. 
JOKIĆ Ž., KOVČIN S., HRISTOV S. (1996): Uloga i značaj nekih vitamina u intenzivnoj proizvodnji svinja. Veterinarski glasnik, 50, 1-2, 91-99.

KASALICA T., ŽIVKOVIĆ B., POPOV D., MILIDRAGOVIĆ N., JERKOVIĆ B. (1995): Uloga, značaj i potrebe vitamina u ishrani svinja. IX Savetovanje agronoma i tehnologa, Smederevo, 118-123.

KOVČIN S., GAGRČIN M., JOKIĆ Ž. (1992): Značaj sadržaja vitamina u premiksu krmača. III Savetovanje o primeni premiksa u stočnoj hrani, Donji Milanovac.

LEE C.E., KIM K.I. (2001): Effect of deletion of vitamin and trace mineral premixes from diets on daily gain, feed:gain ratio, backfat thickness, red blood cell count in finishing pigs. Journal of Animal Science, 79, Supplement 1, 453.

POMAR C., HAUSCHILD L., ZHANG G.H., POMAR J., LOVATTO P.A. (2009): Applying precision feeding techniques in growing-finishing pig operations. R. Bras. Zootec., 38, spe Viçosa.

PUPAVAC S., SINOVEC Z., JERKOVIĆ B. (1998): Uticaj korišćenja predsmeša različitog sastava na proizvodne rezultate svinja u tovu. XII Savetovanje agronoma i tehničara, Aranđelovac, 369-376.

REA J.C., VEUM T. (1993): Evaluating vitamin Premixes fro Swine. University of Missouri.

SHURSON G.C., SALZER T.M., KOEHLER D.D., WHITNEY M.H. ( 1997): Effect of Metal Specific Amino Acid Complexes and Inorganic Tece Minerals on vitamin Stability in Premixes. ASAS Midwestern Section Mtg., Des Moines, IA, March 17-19.

ŠEFER D., SINOVEC Z. (1999): Novija dostignuća u suplementaciji životinja mikroelementima. I Simpozijum iz oblasti veterinarske nauke i proakse, Zlatibor, 101-110.

ZLATIĆ H. (1983): Značaj i uloga premiksa u ishrani stoke i proizvodnji stočne hrane. Krmiva, 1-2-, 8-10.

ŽIVKOVIĆ B., MIGDAL W., KOSOVAC O., RADOVIĆ Č., DELIĆ N., PEJČIĆ S. (2010): The effects of different pre-mixtures in nutrition of sows and piglets. Biotechnology in Animal Husbandry, 26 (1-2), p 47-55.

ŽIVKOVIĆ B. , KOVČIN S., GLUHOVIĆ M., KOSOVAC O., VLAHOVIĆ M., FABJAN M. (1996): Značaj i primena premiksa u proizvodnji svinjskog mesa. V savetovanje o primeni premiksa u stočnoj hrani, Velika Plana. Veterinarski Zavod, Zemun, 12-18.

ŽIVKOVIĆ B., RUSMIROVIĆ D., STANOJLOVIĆ R. (2005): Efekti premiksa sa povećanim koncentracijama vitamina i mikroelemenata $u$ ishrani svinja $u$ tovu. Euro Farmer, 5-6, 26-30.

ŽIVKOVIĆ S., KOVČIN S. (1983): Vitamini i mikroelementi u ishrani svinja. Krmiva 1-2, 26-30. 